\title{
Free flap head and neck reconstruction in the elderly: what is the impact on quality of life?
}

\author{
Ricostruzione testa-collo mediante lembi rivascolarizzati nella popolazione anziana: \\ quale impatto sulla qualità della vita?
}

\author{
A. FERRI ${ }^{1}$, E. SEGNA ${ }^{2}$, A. VARAZZANI ${ }^{1}$, C. COPELLI ${ }^{3}$, S. VALSECCHI ${ }^{4}$, G. DELL'AVERSANA ORABONA ${ }^{5}$, A. BAJ $^{2}$ \\ ${ }^{1}$ Maxillo-Facial Surgery Division, Head and Neck Department, University Hospital of Parma, Italy; ${ }^{2}$ Oral and Maxillofacial \\ Surgery, Hospital Maggiore Policlinico of Milano, Italy; ${ }^{3}$ Maxillo-Facial Surgery Operative Unit, Hospital Casa Sollievo della \\ Sofferenza, San Giovanni Rotondo (FG), Italy; ${ }^{4}$ Unit of Maxillofacial Surgery, Hospital S. Anna, Como, Italy; ${ }^{5}$ Maxillofacial \\ Surgery Unit, University Hospital of Naples Federico II, Naples, Italy
}

\section{SUMMARY}

Morphofunctional reconstruction is a pivotal aspect in the surgery of head and neck neoplasms: nowadays, microvascular free flap surgery represents the gold standard. In choosing the surgical technique, the effects on residual quality of life, especially in elderly people, usually considered more fragile and so often excluded from microsurgical procedures, must be taken into account. This multicentre study evaluated the quality of life index in patients more than 75 years of age and who underwent to head and neck microsurgical reconstruction. Data from patients aged $>75$ years at the time of major head and neck reconstruction conducted with free flaps between 1 January 2005 and 30 June 2015 were analysed retrospectively. We administered the Italian version of Quality of Life questionnaire SF-36, at least 24 months after surgery. Results were compared to those for the general Italian population of the same age. We enrolled 39 patients with an average age of 80.6 years. The results did not differ significantly from the reference population. The international literature has already shown that chronologic age is not a valid parameter to determine the surgical treatment modality. Even considering the quality of residual life, our study supports the indication for free-flap reconstruction of head and neck defects in the elderly, confirming its effectiveness in this population.

KEY WORDS: Head and neck cancer • Free tissue flaps $\bullet$ Reconstructive microsurgery $\bullet$ Quality of life $\bullet$ Patient health questionnaire

\section{RIASSUNTO}

La ricostruzione dei difetti della regione testa-collo costituisce un momento fondamentale del trattamento delle neoplasie di questo distretto in considerazione delle criticità estetiche e funzionali delle strutture coinvolte. In tale contesto le tecniche microvascolari rappresentano ad oggi il gold-standard. Tuttavia, le indicazioni a tali tecniche dovrebbero tenere in considerazione anche l'impatto delle procedure sulla qualità della vita residua, in particolare nella popolazione anziana, generalmente considerata più fragile e pertanto spesso non candidata a metodiche microchirurgiche. Lo studio, condotto con un disegno multicentrico, mira a valutare la qualità della vita nei pazienti anziani sottoposti a ricostruzione con lembi liberi per verificare l'appropriatezza delle indicazioni in questa particolare popolazione. Sono stati raccolti i dati di tutti i pazienti di età $>75$ anni al momento della ricostruzione microvascolare testa-collo, tra il 1 gennaio 2005 e il 30 giugno 2015. Il questionario per qualità della vita SF36 è stato quindi somministrato ad almeno 24 mesi di follow up. Dai risultati dell'SF36 abbiamo inoltre estrapolato anche i valori sintetici PCS (Physical health Composite Score) e MCS (Mental health Composite Score). I risultati sono stati confrontati con gli score della popolazione normale della stessa fascia di età. Sono stati arruolati 39 pazienti, con età media di 80,6 anni, con follow-up medio di 49,3 mesi. La letteratura internazionale conferma che è il profilo biologico del paziente e non l'età anagrafica che dovrebbe determinare l'indicazione alla ricostruzione microvascolare. Pochi lavori hanno invece analizzato l'outcome del paziente in termini di qualità della vita residua. Questo studio conferma che le metodiche microvascolari possono essere utilizzate con sicurezza anche nella popolazione over 75 , senza impattare significativamente sulla qualità di vita residua.

PAROLE CHIAVE: Tumori testa e collo $\bullet$ Lembi liberi microchirurgici $\bullet$ Microchirurgia ricostruttiva $\bullet$ Qualità della vita $\bullet$ Questionari di valutazione della salute

\section{Introduction}

The global increase in the mean lifespan and improvements in medical science have raised issues related to surgical approaches in elderly patients ${ }^{1}$. In particular, when primary functions such as swallowing, breathing and speaking are impaired, as is inevitable when treating malignancies in the upper aero-digestive tract, the importance of patient recovery and impact on the quality of residual life after surgical treatment should not be underestimated $^{23}$. Many authors have recently examined these 
issues, with particular focus on indications, success rates, complications and perioperative morbidity related to free-flap reconstruction in elderly patients with oral cavity tumours ${ }^{4-8}$. Most authors have concluded that comorbidities and performance status, rather than age, should be considered as risk and predictive factors ${ }^{9}$, as free-flap techniques are believed to be relatively safe in the elderly population ${ }^{1011}$.

However, little research has focused on the impact of such reconstruction on the quality of life (QOL) of elderly patients. Thus, we require a better understanding of patients' QOL after tumour treatment, in terms of surgery-related long-term morbidity, social life impairment and the psychological implications of such major interventions in a subset of patients usually considered to be frail. Comprehensive insight into this matter is of primary importance to better determine whether these procedures are indicated in the elderly population, as the quality of residual life (which is obviously shorter than in younger patients) is a primary issue that should be taken into account when treating these patients. In this study, we analyse the impact of major resection and reconstructive procedures on QOL in the population of patients over the age of 75 .

\section{Patients and methods}

This multicentre retrospective review of medical records involved five Italian academic tertiary-care institutions: the University Hospital of Parma, University Hospital Maggiore Policlinico of Milano, "Sant'Anna" Hospital of Como, University Hospital "Federico II" of Napoli, and "Casa Sollievo della Sofferenza" Hospital of San Giovanni Rotondo. Data from patients aged $>75$ years at the time of major head and neck reconstruction conducted with free flaps between 1 January 2005 and 30 June 2015 were analysed retrospectively. The data collected included age, sex, American Society of Anesthesiologists (ASA) status, alcohol and tobacco habits, history of oncological pathology, and comorbidities in four major areas (cardiovascular, kidney, liver, and lung). Data related to treatment included diagnosis, staging, site involved, need for neck dissection, free flap type, adjuvant treatments and need for permanent feeding or breathing support (i.e., tracheostomy, percutaneous endoscopic gastrostomy [PEG]).

The validated Italian version of the Medical Outcome Study's (MOS's) 36-item Short-Form Health Survey (SF36), administered at least 24 months after surgery, was used to assess QOL ${ }^{12}$. The SF-36 investigates eight fields of global health, focusing on emotional and physical aspects, with scores ranging from 0 to 100. The Short Form 12 (SF12) can be used to condense SF-36 scores into the medical component summary (MCS) and physical component summary (PCS) scores, simplifying analysis of data ${ }^{13}$. Results with the SF-12 were compared to those for the general Italian population of the same age using a database of 61,434 questionnaires completed by Italian subjects ${ }^{14}$.

\section{Results}

For the period considered, 115 patients met inclusion criteria. $76(66.1 \%)$ of patients died before data collection and were not included. Thus, the study cohort consisted of 39 patients (19 males and 20 females) with an average age at the time of surgery of $80.6 \pm 4.40$ years (maximum age, 89 years; Table I). The average followup duration was 49.3 months (range, 24-132 months). Comorbidities ( $86 \%$ of which were cardiovascular disease) were recorded in 32 patients. ASA indices were 3 for $59 \%$ of patients, 2 for $33 \%$ of patients, 4 for $5 \%$ of patients and 1 for $2 \%$ of patients. In all, 15 patients were smokers, 11 abused alcohol and 8 had both habits. All patients required microvascular reconstruction due to malignant pathology: 33 patients had squamous cell carcinoma of the oral cavity, 4 had cutaneous squamous cell carcinoma, 1 was treated for basal cell carcinoma infiltrating the maxilla and 1 had adenocarcinoma of the minor salivary gland. The most frequently involved oralcavity site was the mandible (in $36 \%$ of patients), followed by the tongue (21\%), cheek (13\%), maxilla (13\%), and floor of the mouth $(8 \%)$. The skin was involved in $10 \%$ of patients. $20(51 \%)$ patients had advanced (stage IV) disease, six had stage III, 9 had stage II and 4 had stage I disease. Bone-containing free flaps were used in 7 patients (five fibula flaps, two iliac crest flaps), and the most frequently used flap was the radial forearm free flap $(n=20)$. Other flaps harvested were the latissimus dorsi $(\mathrm{n}=10)$ and antero-lateral thigh $($ ALT; $\mathrm{n}=2)$ flaps. Neck dissection was performed in 30 patients. 23 patients underwent post-surgical adjuvant radiotherapy, two underwent chemotherapy and 1 patient was given both treatments. No permanent tracheostomies were recorded; three patients underwent permanent PEG. We recorded 10 cases of disease relapse, and three patients died after completing the questionnaire.

The questionnaire results are summarised in Table II. The average score for all patient scales was $68.29 \pm 27.30$; the highest score was for physical function $(76.92 \pm 25.35)$ and the lowest score was for energy/fatigue $(60.25 \pm 19.26)$. SF-12 results are shown in Figures 1-3. We divided the cohort into two groups according to sex and compared our results with those from the control group, which comprised 5,283 Italian 
Table I. Patient characteristics $(n=39)$.

\begin{tabular}{|c|c|}
\hline & N (\%) \\
\hline $\begin{array}{l}\text { Sex } \\
\text { Male } \\
\text { Female }\end{array}$ & $\begin{array}{l}19(49 \%) \\
20(51 \%)\end{array}$ \\
\hline $\begin{array}{l}\text { Comorbidities } \\
\text { Yes } \\
\text { Renal } \\
\text { Pulmonary } \\
\text { Cardiovascular } \\
\text { Hepatic } \\
\text { No }\end{array}$ & $\begin{array}{c}22(56 \%) \\
0(0 \%) \\
2(5 \%) \\
19(49 \%) \\
1(2 \%) \\
17(44 \%)\end{array}$ \\
\hline $\begin{array}{l}\text { Smoking } \\
\text { Yes } \\
\text { No }\end{array}$ & $\begin{array}{l}15(38 \%) \\
24(62 \%)\end{array}$ \\
\hline $\begin{array}{c}\text { Alcol } \\
\text { Yes } \\
\text { No }\end{array}$ & $\begin{array}{l}11(28 \%) \\
28(72 \%)\end{array}$ \\
\hline $\begin{array}{c}\text { ASA } \\
\text { I } \\
\| \\
\text { III } \\
\text { IV }\end{array}$ & $\begin{array}{c}1(2 \%) \\
13(33 \%) \\
23(60 \%) \\
2(5 \%)\end{array}$ \\
\hline $\begin{array}{l}\text { Pathology } \\
\text { Squamous cell carcinoma oral cavity } \\
\text { Cutaneous squamous cell carcinoma } \\
\text { Cutaneous basal cell carcinoma } \\
\text { Adenocacinoma salivary gland }\end{array}$ & $\begin{array}{c}33(87 \%) \\
4(9 \%) \\
1(2 \%) \\
1(2 \%)\end{array}$ \\
\hline $\begin{array}{l}\text { Tumour site } \\
\text { Mandible } \\
\text { Tongue } \\
\text { Maxillary bone } \\
\text { Cheek } \\
\text { Floor of the mouth } \\
\text { Skin }\end{array}$ & $\begin{array}{l}14(36 \%) \\
8(21 \%) \\
5(13 \%) \\
5(13 \%) \\
3(8 \%) \\
4(9 \%)\end{array}$ \\
\hline $\begin{array}{l}\text { Disease stage } \\
\text { I } \\
\text { III } \\
\text { IV }\end{array}$ & $\begin{array}{c}4(9 \%) \\
9(24 \%) \\
6(16 \%) \\
20(51 \%)\end{array}$ \\
\hline $\begin{array}{l}\text { Type of flap } \\
\text { Forearm } \\
\text { Fibula } \\
\text { lliac crest } \\
\text { ALT } \\
\text { Latissimus dorsi }\end{array}$ & $\begin{aligned} 20 & (51 \%) \\
5 & (13 \%) \\
2 & (5 \%) \\
10 & (26 \%) \\
2 & (5 \%)\end{aligned}$ \\
\hline $\begin{array}{l}\text { Neck dissection } \\
\text { Yes } \\
\text { No }\end{array}$ & $\begin{array}{c}7(18 \%) \\
32(72 \%)\end{array}$ \\
\hline $\begin{array}{l}\text { Adjuvant therapy } \\
\text { Yes } \\
\text { No }\end{array}$ & $\begin{array}{l}26(67 \%) \\
13(33 \%)\end{array}$ \\
\hline
\end{tabular}

people aged $>75$ years. The most evident difference was in the PCS score (46.53 vs 37.85 ), which indicated that our patients perceive themselves to have a better physical status than their counterparts from the general population.

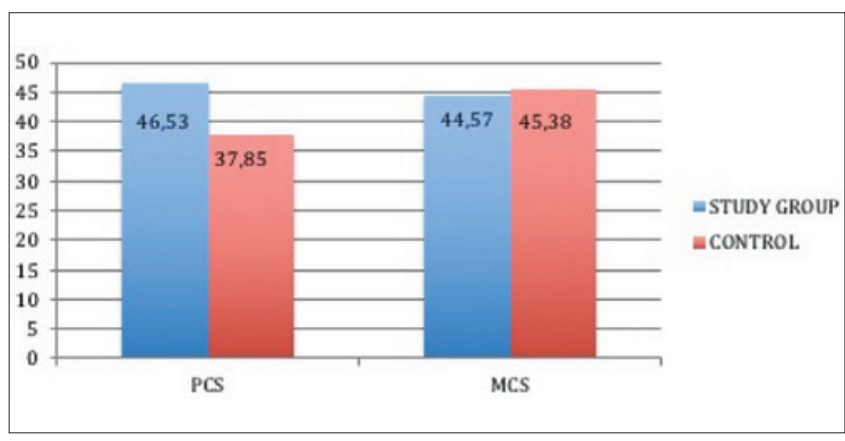

Fig. 1. SF-12 results, all patients.

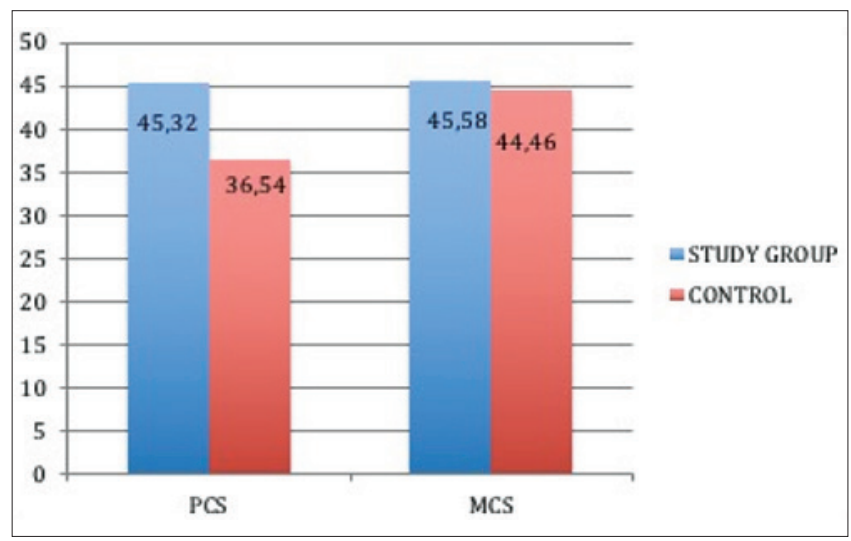

Fig. 2. SF-12 results, female group.

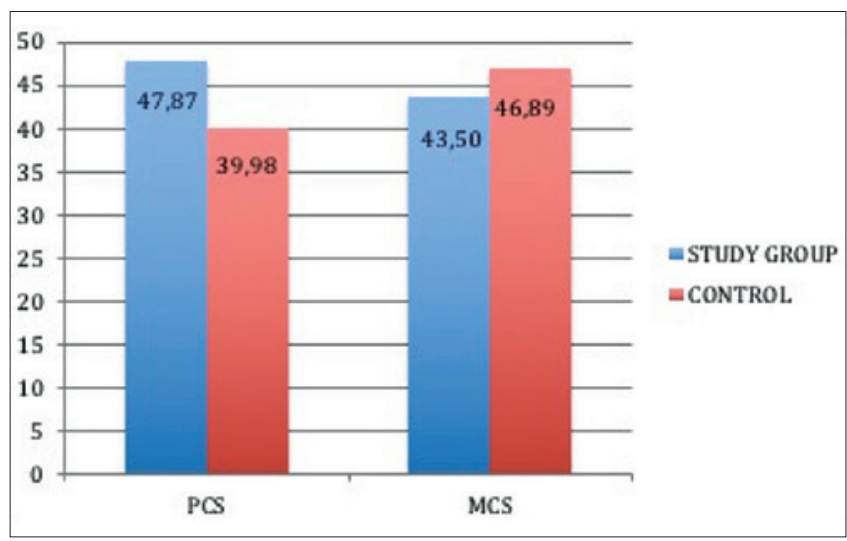

Fig. 3. SF-12 results, male group.

\section{Discussion}

When surgical results after head and neck resection and reconstruction in the elderly population are analysed, several major issues must be considered. The most relevant issues are that most of these patients are extremely frail, and long-term follow-up is difficult to achieve due to death of subjects resulting from multiple possible events (e.g., cardiovascular events, sec- 
Table II. Results obtained in the 8 fields of SF-36 questionnaires.

\begin{tabular}{lccccc} 
SF-36 & Mean & Average & SD & Min & Max \\
Physical functioning & 85 & 76.92 & \pm 25.35 & 0 & 100 \\
Role limitations due to physical health & 100 & 66.66 & \pm 41.09 & 0 & 100 \\
Pain & 74 & 72.76 & \pm 27.18 & 0 & 100 \\
General health & 61 & 60.48 & \pm 17.85 & 25 & 100 \\
Energy/fatigue & 60 & 60.25 & \pm 19.26 & 15 & 95 \\
Social functioning & 75 & 72.23 & \pm 24.87 & 0 & 100 \\
Role limitations due to emotional problems & 100 & 67.46 & \pm 43.62 & 0 & 100 \\
Emotional well-being & 72 & 69.53 & \pm 19.15 & 28 & 100 \\
\hline
\end{tabular}

ondary tumour development). Our case series confirms this trend, as two-thirds of patients died before our retrospective evaluation, which makes assessment of the real impacts of these procedures on patient survival and the effectiveness of reconstructive surgery in terms of QOL extremely difficult. Moreover, recruitment of survivors introduces selection bias because this group likely includes only those with the highest performance status, partially affecting comparison with the general population of the same age. This bias was further increased in our series because we considered only patients who were candidates for free-flap surgery, resulting in the exclusion of those in worst general condition at the time of treatment.

No consensus has been reached in the international literature on the official definition of "elderly", with various cut-off ages used in different studies ${ }^{15-17}$. However, 75-80 years of age is considered worldwide to be a welldefined landmark, probably because the percentage of comorbidities and general performance status are more constant in individuals who have reached this age range than in the younger population, in which these parameters can markedly differ among patients of the same age and are usually considered the most important criteria in patient evaluation.

All of these findings underline the difficulty of dealing with this specific group of patients and partially explain the relative paucity of papers with a large series of elderly patients ${ }^{18}$. Our inclusion criteria were thus quite broad, and the data were not stratified based on surgical site or adjuvant treatment. This approach was taken in part due to the small sample, and in part based on our goal of examining the impact of free-flap surgery in these subjects. We believe that it was adequate for the examination of patients in this cohort.

Few studies have focused on QOL in these elderly subjects, probably due to the difficulty of analyses. A multicentric study design is mandatory to achieve a sufficiently large study cohort for such analyses. Although its importance is often underestimated, long-term QOL is of ex- treme relevance in analyses of surgical results because it represents a final assessment of treatment; thus, it should be considered a real outcome to measure ${ }^{19}$, particularly for patients with relatively short remaining life expectancies, such as octogenarians. The intent is to assess whether major surgical procedures, usually considered the best reconstructive options in the general population ${ }^{20}$, are justified by the achievement of satisfactory QOL, or whether possible associated risks and shortcomings ${ }^{2122}$, which can lead to impairment and other consequences that compromise final outcomes, outweigh potential benefits.

QOL should be assessed through analyses of daily life activities and functions, and questionnaires are considered among the best methods by which to investigate this parameter ${ }^{23}{ }^{24}$. When results from the general population are available, comparison with cohort data can further improve the value of the results and provide a more objective view of the scores. This consideration is the main reason that we chose to use the SF-36 and SF-12. Our choice was also made with consideration of the availability of the questionnaire in patients' native language and its international validation ${ }^{12}$. The results of this study are quite encouraging, particularly in consideration of physical impairment; the mean general physical function was $76.92 / 100$, and pain (72.76/100) was not an issue for our patients. Energy/fatigue and general health were the most relevant problems, with scores of 60.25 and 60.48/100, respectively, but these factors are probably those most biased by the age of the subjects. SF-12 scores were comparable with those of the general population; the PCS score was slightly better than that of the control group, and the MCS score was basically the same as that from the general population. Considering the selection of the "healthiest" subjects based on the indication for free-flap procedures, this analysis showed that free-flap reconstruction does not worsen the quality of residual life in elderly patients. These findings, together with those from the literature, confirm that free-flap success rates and complications in this population are comparable to those in 
younger patients, which should help surgeons in surgical planning, reducing concerns about elderly patients' postsurgical daily lives.

\section{Conclusions}

Our data support the indication for free-flap reconstruction of head and neck defects in the elderly population. In particular, the quality of residual life seems to be comparable to that in the general population of the same age. Further studies should be conducted to assess whether the high mortality rate is related only to general age-related risks, or whether major surgical procedures play a contributing role.

\section{Conflict of interest statement}

None declared.

\section{References}

1 Korc-Grodzicki B, Downey RJ, Shahrokni A, et al. Surgical considerations in older adults with cancer. J Clin Oncol 2014;32:2647-53.

2 Cohen WA, Albornoz CR, Cordeiro PG, et al. Health-related quality of life following reconstruction for common head and neck surgical defects. Plast Reconstr Surg 2016;138:1312-20.

3 Murphy BA, Ridner S, Wells N, et al. Quality of life research in head and neck cancer: a review of the current state of the science. Crit Rev Oncol Hematol 2007;62:251-67.

4 Ferrari S, Copelli C, Bianchi B, et al. Free flaps in elderly patients: Outcomes and complications in head and neck reconstruction after oncological resection. J Craniomaxillofac Surg 2013;41:167-71.

5 Tarsitano A, Pizzigallo A, Sgarzani R, et al. Head and neck cancer in elderly patients: is microsurgical free-tissue transfer a safe procedure? Acta Otorhinolaryngol Ital 2012;32:371-5.

6 Howard MA, Cordeiro PG, Disa J, et al. Free tissue transfer in the elderly: incidence of perioperative complications following microsurgical reconstruction of 197 septuagenarians and octogenarians. Plast Reconstr Surg 2005;116:1659-68.

7 Üstün GG, Aksu AE, Uzun H, et al. The systematic review and meta-analysis of free flap safety in the elderly patients. Microsurgery 2017;37:442-50.

8 Szturz P, Vermorken JB. Treatment of elderly patients with squamous cell carcinoma of the head and neck. Front Oncol 2016;6:199.

9 Goh CS, Kok YO, Yong CP, et al. Outcome predictors in elderly head and neck free flap reconstruction: a retrospective study and systematic review of the current evidence. J Plast Reconstr Aesthet Surg 2018;71:719-28.

10 Peters TT, Post SF, van Dijk BA, et al. Free flap reconstruction for head and neck cancer can be safely performed in both young and elderly patients after careful patient selection. Eur Arch Otorhinolaryngol 2015;272:2999-3005.

11 Piazza C, Grammatica A, Paderno A, et al. Microvascular head and neck reconstruction in elderly: the University of Brescia experience. Head Neck 2016;38(Suppl 1):E1488-92.

12 Apolone G, Mosconi P. The Italian SF-36 health survey: translation, validation and norming. J Clin Epidemiol 1998;51:1025-36.

13 Ware JE, Kosinski M, Keller SD. A 12-item Short Form Health Survey: construction of scales and preliminary tests of realiability and validity. Med Care 1996;34:220-33.

14 Apolone G, Mosconi P, Quattrociocchi L, et al. Questionario sullo stato di salute $S F-12$. Versione italiana. Milano: Guerini e Associati Editore 2005.

15 Chen XF, Chen YM, Gokavarapu S, et al. Free flap reconstruction for patients aged 85 years and over with head and neck cancer: clinical considerations for comprehensive care. Br J Oral Maxillofac Surg 2017;55:793-7.

16 Fagin AP, Gelesko S, Wax MK, et al. Morbidity and functional outcomes with head and neck free flap reconstruction in patients aged 90 years or older. J Oral Maxillofac Surg 2017;75:1549-54.

17 Ozkan O, Ozgentas HE, Islamoglu K, et al. Experiences with microsurgical tissue transfers in elderly patients. Microsurgery 2005;25:390-5

18 Khafif A, Posen J, Yagil Y, et al. Quality of life in patients older than 75 years following major head and neck surgery. Head Neck 2007;29:932-9.

19 Murphy BA, Ridner S, Wells N, et al. Quality of life research in head and neck cancer: a review of the current state of the science. Crit Rev Oncol Hematol 2007;62:251-67.

20 Copelli C, Tewfik K, Cassano L, et al. Management of free flap failure in head and neck surgery. Acta Otorhinolaryngol Ital 2017;37:387-92.

21 Segna E, Bolzoni AR, Baserga C, et al. Free flap loss caused by heparin-induced thrombocytopenia and thrmobosis (HITT): a case report and literature review. Acta Otorhinolaryngol Ital 2016;36:527-33.

22 Baj A, Bolzoni AR, Torretta S, et al. Arterial microanastomoses on the reverse flow of the internal carotid artery reverse flow: an extreme solution in free-flap revascularisation. How we do it. Acta Otorhinolaryngol Ital 2014;34:368-71.

23 Hikosaka M, Ochiai H, Fujii M, et al. QOL after head and neck reconstruction: evaluation of Japanese patients using SF-36 and GOHAI. Auris Nasus Larynx 2011;38:730-4.

24 Rogers SN, Humphris G, Lowe D, et al. The impact of surgery for oral cancer on quality of life as measured by the Medical Outcomes Short Form 36. Oral Oncol 1998;34:171-9.

\section{Received: March 12, 2018 - Accepted: April 19, 2018}

How to cite this article: Ferri A, Segna E, Varazzani A, et al. Free flap head and neck reconstruction in the elderly: what is the impact on quality of life? Acta Otorhinolaryngol Ital 2019;39:145-149. https://doi.org/10.14639/0392-100X-2149

Address for correspondence: Eleonora Segna, Chirurgia Maxillo-facciale e Odontostomatologia, Fondazione IRCCS Ca' Granda Ospedale Maggiore Policlinico di Milano, via Francesco Sforza 35, 20122 Milano, Italy. Tel. +39 02 55032745. Fax +39 02 55032558. E-mail: elesegna@hotmail.it 